\title{
The Assessment of Biochemical Parameters in Patients with Venous Thromboembolism
}

\author{
ADRIAN CRISAN ${ }^{1}$, OVIDIU MITU ${ }^{1,2 *}$, IRINA IULIANA COSTACHE ${ }^{1,2}$, RADU MIFTODE $^{1,2}$, \\ CRISTIAN MIHAI STEFAN HABA ${ }^{1,2}$, IVONA MITU ${ }^{2}$, DANIELA-CRISTINA DIMITRIU ${ }^{2}$, \\ ANTONIU OCTAVIAN PETRIS ${ }^{1,2}$ \\ ${ }^{1}$ Clinical Emergency Hospital "Sf. Spiridon", Department of Cardiology, Iasi, Romania \\ ${ }^{2}$ University of Medicine and Pharmacy "Grigore T. Popa” Iasi, Romania
}

\begin{abstract}
Assessing the biochemical parameters in patients with pulmonary embolism (PE), deep vein thrombosis $(D V T)$ or both brings complimentary information for the cardiovascular $(C V)$ and death risk stratification. The purpose of the study was to evaluate the association between biochemical parameters and PE, DVT or both. The study was prospective, conducted over a 12-month period and included 151 patients diagnosed with PE, DVT or both pathologies. These patients were extensively analysed taking into account biochemical parameters associated with the above-mentioned pathologies. Mean age was $59.23 \pm 18.22$ years and $55 \%$ were women. $38.40 \%$ patients had PE, $48.30 \%$ had DVT and $13.20 \%$ had both pathologies. GFR upon admission was strongly negatively associated with age, $r(148)=-0.75, p<0.01$, intra-hospital death $r(148)=-0.18, p=0.02$ and with AST levels $r(144)=-0.21, p=0.01$ and positively statistically significant with the number of days of hospitalization $r(8)=+0.79, p=0.0$. Moreover, for one unit decrease in GFR the number of days of hospitalization decreased with 0.231. Moreover, AST correlated with intra-hospital death $r(146)=$ $0.25, p<0.01$, creatinine upon admission $r(144)=0.24, p<0.01$, urea upon admission $r(143)=0.16$, $p=0.04$ and glucose levels $r(139)=0.19, p=0.02$, but negatively associated with GFR upon admission with $r(144)=-0.21, p=0.01$; for each one unit decrease of GFR there was an increase in AST levels by 0.21. Also there was a significant correlation between the thrombolysis therapy and the number of days of hospitalization $r(151)=0.21, p<0.01$ and between positive inotropic support and intra-hospital death with $r(151)=0.27, p<0.01$. In patients with PE, DVT or both, renal function, AST levels and the number of days of hospitalization were associated with an increased risk of death, especially in patients with $P E \pm D V T$.
\end{abstract}

Keywords: biochemical parameters, pulmonary embolism, deep vein thrombosis, venous thrombembolism

\section{Introduction}

Venous thromboembolism (VTE), clinically presenting as deep vein thrombosis (DVT) or pulmonary embolism (PE), is globally the third most frequent acute cardiovascular syndrome after myocardial infarction and stroke [1]. Annual incidence rates for PE range from 39-115 per 100.000 population. The incidence of VTE is almost eight times higher in individuals aged $\geq 80$ years than in the fifth decade of life [2-3]. Incidence is steadily increasing because of the population ageing, the higher prevalence of comorbidities associated with VTE such as obesity, heart failure and cancer, and the improved sensitivity and widespread use of imaging tests to detect VTE [1-4]. VTE is associated with substantial morbidity and mortality. Although the 30-day mortality rate after PE is decreasing [5,6], about $20 \%$ of patients with PE still die before diagnosis or shortly after, particularly if PE is associated with haemodynamic instability [7]. On long term, VTE is a chronic disease and about $30 \%$ of all patients present recurrence within 10 years $[8,9]$.

\footnotetext{
*email:mituovidiu@yahoo.co.uk
} 
The evaluation of the biochemical parameters is very important both for clinical and subclinical disease [10]. In case of PE and DVT, the biochemical parameters can estimate the risk of bleeding or death in patients treated with different therapy agents and should be evaluated for dose adjustment for all administrated drugs. The evaluation of renal function is mostly recommended since it shows a correlation with the risk of bleeding, fatal bleeding or fatal PE [11-15] and is recommended before starting an anticoagulant therapy $[1,14]$. On the other hand, liver function is as important as the renal function in VTE patients because it is associated with increased hospital length of stay [16-18] and cost [19], leading to increased health care burden, in addition to worsening patient outcomes [16,20].

The aims of the current study were to assess the biochemical parameters in patients with PE and DVT and to identify the main biochemical parameters associated with a prognostic role for the risk of death in this population.

\section{Material and methods}

The current study was prospective, conducted over a 12-month period and included 151 patients diagnosed with DVT, PE or both. These patients were extensively analysed taking into account biochemical parameters associated with the pathologies presented in our study. Patients have been diagnosed with PE and DVT according to the current guidelines [1]. All patients signed an informed consent for inclusion in the study.

The exclusion criteria were: the refusal of patients to participate in the study; the presence of a cancer in terminal stage; major cardiovascular complications (myocardial infarction, stroke, cardiac or peripheral revascularization).

The following biochemical parameters have been assessed: haemoglobin $(\mathrm{Hb})$, haematocrit $(\mathrm{Ht})$, platelets, glucose level, total cholesterol and its fractions (HDL-cholesterol and LDL-cholesterol), triglycerides, hepatic function (AST and ALT) and renal function characterised by levels of urea, creatinine and glomerular filtration rate (GFR) upon admission and discharge. Moreover, we assessed the age, gender, the body mass index (BMI), smoker status and alcohol consumption, as well as hemodynamic parameters: systolic blood pressure - SBP, diastolic blood pressure - DBP and heart rate - HR upon admission and discharge. Also, we were interested in the treatment followed by patients during the hospitalization period as well as the number of days that were inpatient before proper discharge or death.

Statistical analysis was performed in SPSS 22.0. The existence of a relationship between variables was evaluated using Pearson correlation coefficient and linear regression equation were conducted to observe how two or more variables vary between them. Descriptive data is presented as mean \pm standard deviation. A p value $<0.05$ was considered statistically significant.

\section{Results and discussions}

The patients mean age was $59.23 \pm 18.22$ years and $55 \%$ of them were women. $38.40 \%$ patients in our group had PE (55.17\% being women), $48.30 \%$ patients had DVT (57.53\% being women) and only $13.20 \%$ patients had both PE and DVT (45\% being women).

Regarding the biochemical parameters, a series of tests were applied to evaluate the variation of these parameters within the three studied groups. The main characteristics of the study group and a list of statistically significant correlations of parameters obtained by a series of ANOVA tests is highlighted in table 1.

Table 1. The main characteristics of the study group

\begin{tabular}{|l|l|l|l|l|l|}
\hline \multirow{2}{*}{ Group profile } & Results & PE & DVT & PE + DVT & p value \\
\cline { 2 - 6 } & All patients & $67.56 \pm 14.12$ & $54.22 \pm 18.60$ & $58.12 \pm 20.67$ & $<0.01$ \\
\hline Age $($ years $)$ & $59.23 \pm 18.22$ & $10.34 \pm 3.81$ & $10.66 \pm 4.41$ & $12.93 \pm 4.00$ & 0.30 \\
\hline Days of hospitalization & $10.72 \pm 5.14$ & $28.92 \pm 5.64$ & $27.35 \pm 5.76$ & $28.35 \pm 4.71$ & 0.32 \\
\hline $\mathrm{BMI}\left(\mathrm{kg} / \mathrm{m}^{2}\right)$ & $28.09 \pm 5.59$ & $12.80 \pm 2.12$ & $12.82 \pm 2.22$ & $13.52 \pm 1.36$ & 0.37 \\
\hline $\mathrm{Hb}(\mathrm{g} / \mathrm{dl})$ & $12.91 \pm 2.09$ & &
\end{tabular}




\begin{tabular}{|l|l|l|l|l|l|}
\hline Platelets $(/ \mu \mathrm{l})$ & $253.380 \pm 10.068$ & $235.017 \pm 89.454$ & $274.535 \pm 10.947$ & $230.421 \pm 86.245$ & 0.04 \\
\hline $\begin{array}{l}\text { Creatinine upon } \\
\text { admission }(\mathrm{mg} / \mathrm{dl})\end{array}$ & $0.91 \pm 0.32$ & $1.03 \pm 0.37$ & $0.82 \pm 0.24$ & $0.87 \pm 0.31$ & $<0.01$ \\
\hline $\begin{array}{l}\text { Urea upon admission } \\
(\mathrm{mg} / \mathrm{dl})\end{array}$ & $41.17 \pm 22.54$ & $50.09 \pm 29.16$ & $34.72 \pm 15.01$ & $39.32 \pm 14.77$ & $<0.01$ \\
\hline $\begin{array}{l}\text { GFR upon admission } \\
\left(\mathrm{ml} / \mathrm{min} / 1.73 \mathrm{~m}^{2}\right)\end{array}$ & $83.27 \pm 26.21$ & $70.21 \pm 24.19$ & $92.50 \pm 24.19$ & $87.49 \pm 24.12$ & $<0.01$ \\
\hline $\begin{array}{l}\text { Creatinine upon } \\
\text { discharge (mg/dl) }\end{array}$ & $0.92 \pm 0.294$ & $0.97 \pm 0.29$ & $0.85 \pm 0.24$ & $0.93 \pm 0.41$ & 0.33 \\
\hline $\begin{array}{l}\text { Urea upon discharge } \\
(\mathrm{mg} / \mathrm{dl})\end{array}$ & $40.40 \pm 20.95$ & $44.50 \pm 25.14$ & $34.89 \pm 15.71$ & $42.33 \pm 15.90$ & 0.09 \\
\hline $\begin{array}{l}\text { GFR upon discharge } \\
\left(\mathrm{ml} / \mathrm{min} / 1.73 \mathrm{~m}^{2}\right)\end{array}$ & $78.35 \pm 25.49$ & $70.90 \pm 24.16$ & $84.48 \pm 26.06$ & $86.28 \pm 23.73$ & 0.08 \\
\hline Glucose (mg/dl) & $119.11 \pm 41.48$ & $128.18 \pm 44.33$ & $115.46 \pm 42.76$ & $109.65 \pm 20.74$ & 0.12 \\
\hline $\begin{array}{l}\text { Total cholesterol } \\
(\mathrm{mg} / \mathrm{dl})\end{array}$ & $182.12 \pm 51.26$ & $169.31 \pm 48.01$ & $191.52 \pm 47.12$ & $184.88 \pm 67.95$ & 0.07 \\
\hline $\begin{array}{l}\text { HDL-cholesterol } \\
(\mathrm{mg} / \mathrm{dl})\end{array}$ & $41.92 \pm 13.76$ & $38.61 \pm 11.44$ & $45.04 \pm 14.98$ & $37.89 \pm 13.65$ & 0.03 \\
\hline $\begin{array}{l}\text { LDL-cholesterol } \\
(\mathrm{mg} / \mathrm{dl})\end{array}$ & $121.33 \pm 42.13$ & $119.86 \pm 43.82$ & $123.25 \pm 37.68$ & $119.91 \pm 52.58$ & 0.34 \\
\hline Triglycerides (mg/dl) & $141.45 \pm 90.22$ & $141.07 \pm 98.14$ & $137.92 \pm 89.49$ & $156.22 \pm 73.70$ & 0.75 \\
\hline AST (U/l) & $25.98 \pm 25.78$ & $36.27 \pm 37.55$ & $22.76 \pm 12.86$ & $20.58 \pm 9.83$ & $<0.01$ \\
\hline ALT (U/l) & $31.87 \pm 36.15$ & $39.93 \pm 47.94$ & $26.88 \pm 28.18$ & $25.80 \pm 14.95$ & 0.09 \\
\hline
\end{tabular}

There was a significant difference among the three groups regarding age, $F(2,148)=8.71, \mathrm{p}<0.01$, platelets $F(2,145)=3.11, \mathrm{p}=0.04$ and HDL-cholesterol with $F(2,113)=3.49, \mathrm{p}=0.03$. Also, the same difference was obtained for AST, $F(2,143)=5.38, \mathrm{p}<0.01$ and the renal function characterized by creatinine upon admission $F(2,145)=7.90, \mathrm{p}<0.01$, urea upon admission $F(2,144)=8.11, \mathrm{p}<0.01$ and GFR upon admission $F(2,145)=13.83$, p $<0.01$.

Analysing the results, both creatinine and urea levels at admission were much higher in case of PE patients compared to the other two groups, result confirmed by the low level of GFR at admission in these patients. Moreover, the AST levels were significantly higher in PE patients than in the other two groups.

A Pearson $\mathrm{r}$ correlation was conducted to examine the relationships between the biochemical parameters in our study group. Age was positively significant associated with creatinine upon admission $\mathrm{r}(148)=0.39, \mathrm{p}<0.01$, creatinine upon discharge $\mathrm{r}(68)=0.43, \mathrm{p}<0.01$, urea upon admission $\mathrm{r}(147)=0.44, \mathrm{p}<0.01$ and urea upon discharge $\mathrm{r}(68)=0.38, \mathrm{p}<0.01$. With glucose levels the results were similar, $\mathrm{r}(144)=0.24$, $\mathrm{p}<0.01$, but was associated in a negative way with number of platelets $r(148)=-0.23, p<0.01$ and GFR upon admission $r(148)=-0.70, p<0.01$.

Urea on admission was negatively related to number of days of hospitalization, $r(147)=-0.21$, $\mathrm{p}<0.01$, number of days of hospitalization till the patient died $\mathrm{r}(8)=-0.78, \mathrm{p}=0.02$ and levels of total cholesterol $\mathrm{r}(123)=-0.18, \mathrm{p}=0.04$ but was positively statistically significant associated with intrahospital death, $\mathrm{r}(147)=+0.25, \mathrm{p}<0.01$ and AST levels $\mathrm{r}(143)=0.16, \mathrm{p}=0.04$. Urea upon admission was strongly positively associated with creatinine upon admission with $\mathrm{r}(147)=+0.69, \mathrm{p}<0.01$.

Taking into account the renal function changes we observed that GFR upon admission was strongly negatively associated with age, $r(148)=-0.75, p<0.01$, intra-hospital death $r(148)=-0.18, p=0.02$ and with AST levels $\mathrm{r}(144)=-0.21, \mathrm{p}=0.01$ but was positively statistically associated with the number of days of hospitalization till the patient death $r(8)=+0.79, p=0.01$. Advancing with the relationship between GFR upon admission and number of days till the patient death (5.29\% of our patients died) a linear regression equation was performed on one scatterplot and the results were $y=-7.08+0.23^{*} \mathrm{x}$ with an $r^{2}$ for this equation of 0.63 . This means that for one unit increase in GFR the number of days of hospitalization increase with 0.231 . More information about this relation can be observed in figure 1 . 


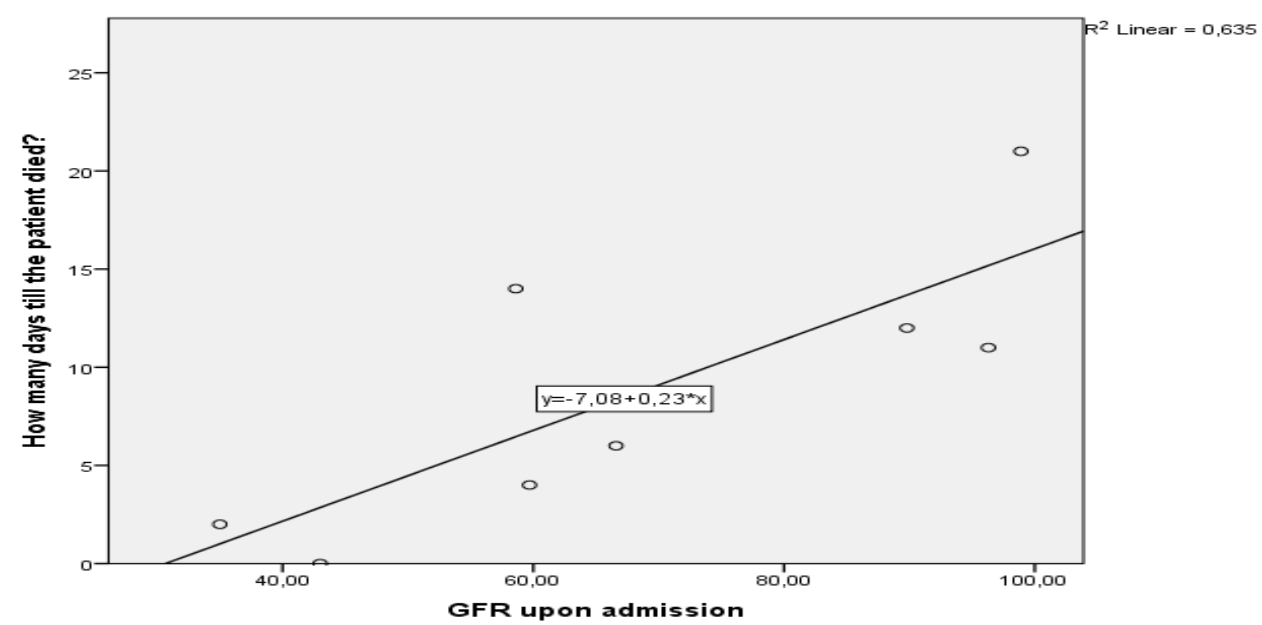

Figure 1. The relationship between GFR upon admission and the number of days till the inpatient death

AST was positively and statistically significant associated with intra-hospital death with $\mathrm{r}(146)=$ $0.25, \mathrm{p}<0.01$ and, in the same line, it was positively and statistically significant associated with creatinine upon admission $\mathrm{r}(144)=0.24, \mathrm{p}<0.01$, urea upon admission $\mathrm{r}(143)=0.16, \mathrm{p}=0.04$ and glucose levels $\mathrm{r}(139)=0.19, \mathrm{p}=0.02$ but negatively and statistically significant associated with GFR upon admission with $\mathrm{r}(144)=-0.21, \mathrm{p}=0.01$. An interesting result was the negative significant association of AST with total cholesterol with an $\mathrm{r}(123)=-0.23, \mathrm{p}=0.01$.

Further on, a linear regression equation was conducted to observe the influence of AST levels compared to the GFR on our study group. The regression equation was $\mathrm{y}=45.50-0.21 * \mathrm{x}$ with an $r^{2}$ for this equation of 0.04 which means that for each one unit of decrease of GFR levels there is an increase by 0.21 in AST levels. More information about this relation can be seen in figure 2 .

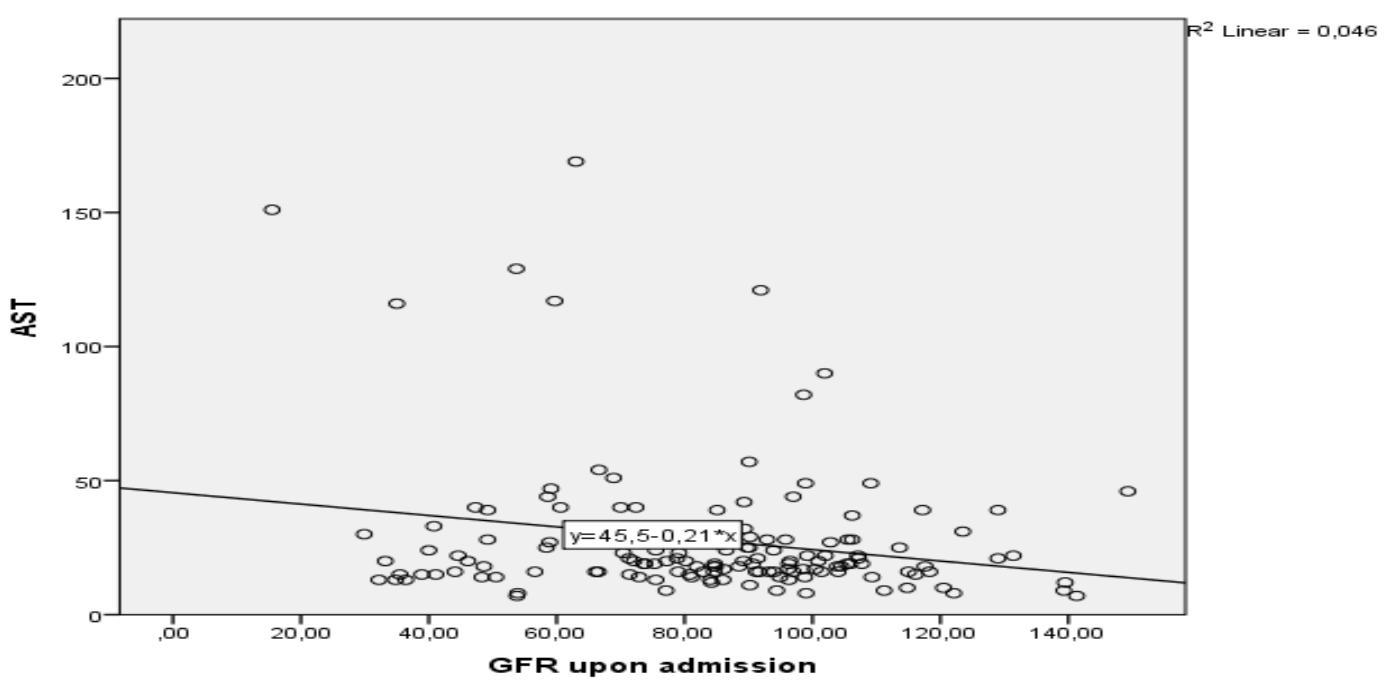

Figure 2. The relationship between GFR upon admission and AST levels

Analysing the drug treatment given to the patients, there was a positive and statistically significant correlation between the therapy with thrombolysis and the number of days of hospitalization $\mathrm{r}(151)=$ $0.21, \mathrm{p}<0.01$ as well as a relationship, in the same way, between positive inotropic support and intrahospital death with $\mathrm{r}(151)=0.27, \mathrm{p}<0.01$.

We also carried out a series of independent $t$ tests to reveal biochemical parameters associated with a prognostic role for death in our group. The renal function, total cholesterol, AST levels, number 
of platelets and the hospitalization days were associated with an increased risk of death. More information can be seen in table 2 .

Table 2. Biochemical parameters associated with high risk of mortality

\begin{tabular}{|c|c|c|c|}
\hline Parameters & Inpatients alive & Inpatients death & p value \\
\hline Number of days of hospitalization & $10.96 \pm 4.03$ & $7.13 \pm 4.48$ & 0.01 \\
\hline Platelets $(/ \mu \mathrm{l})$ & $258.151 \pm 99.608$ & $175.125 \pm 98.230$ & 0.02 \\
\hline Urea upon admission $(\mathrm{mg} / \mathrm{dl})$ & $39.72 \pm 20.24$ & $52.50 \pm 25.84$ & 0.01 \\
\hline Last urea value $(\mathrm{mg} / \mathrm{dl})$ & $37.94 \pm 17.72$ & $64.01 \pm 6.57$ & $<0.01$ \\
\hline GFR upon admission $\left(\mathrm{ml} / \mathrm{min} / 1,73 \mathrm{~m}^{2}\right)$ & $84.47 \pm 25.90$ & $68.48 \pm 24.20$ & 0.02 \\
\hline Last GFR value $\left(\mathrm{ml} / \mathrm{min} / 1,73 \mathrm{~m}^{2}\right)$ & $80.26 \pm 25.01$ & $50.13 \pm 13.25$ & 0.01 \\
\hline Total cholesterol $(\mathrm{mg} / \mathrm{dl})$ & $184.70 \pm 50.85$ & $132.50 \pm 32.27$ & 0.01 \\
\hline AST $(\mathrm{U} / \mathrm{l})$ & $26.01 \pm 23.94$ & $60.57 \pm 40.21$ & 0.01 \\
\hline
\end{tabular}

In this study we aimed to analyse the modifications of biochemical parameters in thromboembolism pathologies like PE, DVT or patients who had both PE and DVT.

By analysing our results both creatinine and urea levels at admission were much higher in case of PE patients compared to the other two groups, result confirmed by the low level of GFR at admission in these patients. Several studies investigated the potential link between VTE and altered renal function. Cook et al. reported that $22.1 \%$ of VTE patients had a creatinine clearance $(\mathrm{CrCl})<60$ $\mathrm{ml} / \mathrm{min}$ [21], but the RIETE register (Registro Informatizado de la Enfer-medad TromboEmbólica) showed that this prevalence was increased over time, with $12.3 \%$ of VTE patients having a $\mathrm{CrCl}<60$ $\mathrm{ml} / \mathrm{min}$ in 2006 and $18.3 \%$ in 2013 [22]. Therefore, there was an increase of $6 \%$ in 7 years between the two publications. Moreover, in our study, by applying a series of independent $t$ tests to reveal biochemical parameters associated with a prognostic role in the risk of death, the modified renal function $\left(\mathrm{CrCl}<70 \mathrm{ml} / \mathrm{min} / 1,73 \mathrm{~m}^{2}\right)$ was associated with a higher risk of death. Other studies have shown that the relationship between modified renal function and VTE was in „both directions”. The LITE (Longitudinal investigation of thromboembolism etiology) study showed that among 19.073 patients followed for 12 years, altered renal function was a risk factor for VTE [23]. Moreover, the risk appeared to be higher at a GFR below $75 \mathrm{ml} / \mathrm{min} / 1,73 \mathrm{~m}^{2}$. Another study confirmed that the increased risk for VTE started for a relatively high value of GFR. In this study, the risk appeared when the GFR reached $88 \mathrm{~mL} / \mathrm{min} / 1.73 \mathrm{~m}^{2}$ in a pooled analysis of 5 prospective studies that included 95.154 patients [24]. In our study the GFR on admission was significantly lower in non-survivors than in survivors $\left(68.48 \pm 24.20\right.$ vs $\left.84.47 \pm 25.90 \mathrm{~mL} / \mathrm{min} / 1.73 \mathrm{~m}^{2}, \mathrm{p}=0.02\right)$ and a similar result was obtained by Maciej Kostrubiec et al. on 2.845 patients $\left(64 \pm 34\right.$ vs. $\left.75 \pm 3 \mathrm{~mL} / \mathrm{min} / 1.73 \mathrm{~m}^{2}, \mathrm{p}<0.0001\right)$ who concluded that GFR calculation should be implemented in the risk assessment of acute PE [25].

Moreover, in the clinical trial published by Maciej K. on 232 patients, the authors concluded that $50 \%$ of patients with acute PE had a moderate impaired renal function on admission and "persistent" renal dysfunction indicated a high mortality rate [26]. Regarding the recurrence of VTE and the relation with renal dysfunction, Yoshiaki T. et al. published results from the COMMAND VTE Registry where GFR $<60 \mathrm{ml} / \mathrm{min} / 1,73 \mathrm{~m}^{2}$ was independently associated with increased risk for recurrent VTE (adjusted HR 1.55, 95\% $\mathrm{Cl} 1.15-2.08$ ) while the risk for recurrent VTE was further increased as GFR decreased [27].

AST was positively and significant associated with intra-hospital death, creatinine upon admission, urea upon admission and is considered to be associated with a high risk of mortality in patients with both PE and DVT. In the study conducted by Aslan et al. on 107 acute PE patients, the results showed that the transaminase levels were higher in patients with acute PE, especially in severe hypoxic patients compared to mild hypoxic patients, the results being associated with a higher risk of mortality in this type of patients [28]. The mechanism of liver injury is probably ischemic due to shock, resulting in low blood flow to the liver and leading to liver cell necrosis [29]. In another study of patients with hypoxic hepatitis, all cases had evidence of a cardiac disorder, with $94 \%$ having right-sided heart failure, the same mechanism that is encountered in PE [30]. 
Nonetheless, there are some limitation of our study. There was a relatively small number of patients $(n=151)$, but the current results may be of future perspective for group enlargement. Secondly, in our patient assessment we did not measure other parameters as the $\mathrm{O}_{2}$ levels or the haemodynamic impact markers as D-Dimers, NT-proBNT or troponin which can precisely classify the VTE patient risk.

\section{Conclusions}

In patients with PE, DVT or both, renal function, AST levels and the number of hospitalization days were associated with an increased risk of death. Moreover, both creatinine and urea levels at admission were much higher in PE patients compared to the other two groups, results confirmed by the lower level of GFR at admission in these patients. Hepatic impairment was severe in patients with both PE and DVT. These results highlight the importance of early and careful monitorization of VTE patients especially when certain biochemical markers are severely modified.

\section{References}

1.KONSTANTINIDES, S. V., MEYER, G., BECATTINI, C., BUENO, H., GEERSING, G. J., HARJOLA, V. P., et al. European Respiratory Journal, 54, no. 3, 2019.

2.RASKOB, G. E., ANGCHAISUKSIRI, P., BLANCO, A. N., BULLER, H., GALLUS, A., HUNT, B. J. ,et al. Arteriosclerosis, thrombosis, and vascular biology, 34, no. 11, 2014, p. 2363-2371.

3.DI NISIO, M., VAN ES, N., \& BULLER, H. R. The Lancet, 388, no. 10063, 2016, p. 3060-3073.

4.HUANG, W., GOLDBERG, R. J., ANDERSON, F. A., KIEFE, C. I., \& SPENCER, F. A. The American journal of medicine, 127, no. 9, 2014, p. 829-839.

5.SOGAARD, K. K., SCHMIDT, M., PEDERSEN, L., HORVATH-PUHO, E., \& SORENSEN, H. T. Circulation, 130, no. 10, 2014, p. 829-836.

6.STEIN, P. D., MATTA, F., ALRIFAI, A., RAHMAN, A. Thrombosis research, 130, no. 6, 2012 ,p. 841-846.

7.GOLDHABER, S. Z., VISANI, L., \& DE ROSA, M. The Lancet, 353, no. 9162, 1999, p. 13861389.

8.HEIT, J. A. Nature Reviews Cardiology, 12, no. 8, 2015, p. 464.

9.KEARON, C. Circulation, 107, no. 23 , 2003, p. 1-22.

10.MITU, O., MITU, F., CONSTANTIN, MML., ROCA, M., GHERASIM, A., GRAUR, M. Rev. Chim., 67, (5), 2016, 953-957.

11.FAlGA, C., CAPDEVIlA, J. A., SOLER, S., RABUNAL, R., MUNOZ SANCHEZ, J. F. S., GALLEDO, P., \& RIETE Investigators. Thrombosis and haemostasis, 98, no.10, 2007, p. 771-776.

12.MONREAL, M., FALGA, C., VALLE, R., BARBA, R., BOSCO, J., BEATO, J. L., \& MAESTRE, A. The American journal of medicine, 119, no. 12, 2006, p. 1073-1079.

13.TRUJILlO-SANTOS, J., LOZANO, F., LORENTE, M. A., ADARRAGA, D., HIRMEROVA, J., DEL TORO, J., ADARRAGA, M. D. The American journal of medicine, 128, no. 1, 2015, p 90-99.

14.JANUS, N., MAHE, I., LAUNAY-VACHER, V., LAROCHE, J. P., \& DERAY, G. Journal des maladies vasculaires, 41, no. 6, 2016, p. 389-395.

15.KELLER, K., BEULE, J., BALZER, J. O., \& DIPPOLD, W.. Experimental gerontology, 100, 2017, p.11-16.

17.AGGARWALl, A., PURI, K. LIANGPUNSAKUL, S. World journal of gastroenterology, 20, no. 19, 2014, p.5737.

17.WU, H. NGUYEN, G.C., Clinical Gastroenterology and Hepatology, 8, no. 9, 2010, p. 800-805. 18.ALDAWOOD, A., ARABI, Y., ALJUMAH, A., ALSAADI, A., RISHU, A., ALDORZI, H., ALQAHTANI, S., ALSULTAN, M. FELEMBAN, A., Thrombosis journal, 9, no. 1, 2011, p.1.

19.ALI, M., ANANTHAKRISHNAN, A.N., MCGINLEY, E.L. SAEIAN, K., Digestive diseases and sciences, 56, no. 7, 2011, p.2152-2159. 
20.WALSH K.A, LEWIS DA, CLIFFORD TM, HUNDLEY JC, GOKUN Y, ANGULO P, DAVIS GA. Annals of Pharmacotherapy, 47, no. 3, 2013, p. 333-339.

21.COOK LM, KAHN SR, GOODWIN J, KOVACS MJ. Journal of Thrombosis and Haemostasis, $\mathbf{5}$, no. 5, 2007, p.937-941.

22.MONREAL, M., FALGA, C., VALLE, R., BARBA, R., BOSCO, J., BEATO, J.L. MAESTRE, A., The American journal of medicine, 119, no. 12, 2006, p.1073-1079.

23.WATTANAKIT, K., CUSHMAN, M., STEHMAN-BREEN, C., HECKBERT, S.R. FOLSON, A.R., Journal of the American society of Nephrology, 19, no. 1, 2008, p.135-140.

24.MAHMOODI, B.K., GANSEVOORT, R.T., NAESS, I.A., LUTSEY, P.L., BRAEKKAN, S.K., VEEGER, N.J., BRODIN, E.E., MEIJER, K., SANG, Y., MATSUSHITA, K. HALLAN, S.I., Circulation, 126, no. 16, 2012, p.1964-1971.

25.KOSTRUBIEC, M., PLYWACZEWSKA, M., JIMENEZ, D., LANKEIT, M., CIURZYNSKI, M., KONSTANTINIDES, S. PRUSZCZYK, P. Thrombosis and haemostasis, 119, no. 01, 2019, p.140148.

26.KOSTRUBIEC, M., LABYK, A., PEDOWSKA-WLOSZEK, J., PACHO, S., DZIKOWSKADIDUCH, O., DUL, P., CIURZYNSKI, M., BIENIAS, P., PRUSZCZYK, P. Thrombosis research, 130 no. 3, 2012, p.37-42.

27.TSUYUKI, Y, YAMASHITA, Y., MORIMOTO, T., AMANO, H., TAKASE, T., HIRAMORI, S., KIM, K., OI, M., KOBAYASHI, Y., ONO, K., AOYAMA, K., KIMURA, T. Thrombosis Research, 187, 2020, p.39-47.

28.ASlan, S., MERAL, M., AKGUN, M., ACEMOGLU, H., UCAR, E.Y., GORGUNER, M. MIRICI, A. Hepatology Research, 37, no. 3, 2007, p.205-213.

29.DUNN, G.D., HAYES, P., BREEN, K.J. SCHENKER, S., The American journal of the medical sciences, 265, no. 3, 1973, p.174-190.

30.SEETO, R.K., FENN, B., ROCKEY, D.C., The American journal of medicine, 109, no. 2, 2000, p.109-113.

Manuscript received: 14.01 .2020 